\title{
Prospective study of ocular and periocular diseases in animals: 188 cases $^{1}$
}

\author{
Matheus V.L. Moreira ${ }^{2}$, Rachel L.A.L. Teixeira Neto², Ingeborg M. Langohr ${ }^{3}$ \\ and Roselene $\mathrm{Ecco}^{2 *}$
}

\begin{abstract}
Moreira M.V.L., Teixeira Neto R.L.A.L., Langohr I.M. \& Ecco R. 2018. Prospective study of ocular and periocular diseases in animals: 188 cases. Pesquisa Veterinária Brasileira 38(3):502-510. Setor de Patologia, Departamento de Clínica e Cirurgia, Escola de Veterinária, Universidade Federal de Minas Gerais, Av. Antônio Carlos 6627, Belo Horizonte, MG 31270-901, Brazil. E-mail: ecco@vet.ufmg.br

Histopathology of the ocular and periocular tissues submitted for diagnosis and research is still incipient in Brazil, in contrast to veterinary clinical ophthalmology. In this study, ocular and periocular tissues from domestic and wild animal species, mainly from the state of Minas Gerais, Brazil, were evaluated between February 2012 and September 2015. The samples were analyzed grossly and microscopically. Histochemistry and immunohistochemistry were performed on some of the samples. The frequency, type of ocular alteration, affected animal species, and affected ocular or periocular tissues were recorded. One hundred eighty-eight ocular and periocular tissues from domestic and, occasionally, wild animals were examined. Nine animals presented two concurrent alterations, adding up to 197 alterations. Proliferative lesions were the most frequent (92), followed by traumatic (43), inflammatory (37), degenerative (18), developmental (4) and vascular/hemorrhagic diseases (3). The globe was the most affected structure (112), followed by eyelids (52), third eyelid (17), bulbar conjunctiva (14) and retrobulbar region (2). Neoplasms arising from periocular tissues were the most frequent alteration (60), possibly related to a more active surgical service and histopathologic evaluation request. Many animals presented ocular lesions that reflected systemic diseases, which were diagnosed by necropsy and examination of other organs. Particularly in cases of neoplasia, early detection and surgical treatment can prevent systemic involvement. Ocular histopathologic evaluation can provide better characterization and prognosis of the clinical-pathological condition of the patient as well.

INDEX TERMS: Ocular diseases, periocular diseases, veterinary ocular pathology, inflammatory diseases, degenerative diseases, traumatic diseases, proliferative lesions, dogs, cats, pathology.
\end{abstract}

\footnotetext{
RESUMO.- [Estudo prospectivo de doenças oculares e perioculares em animais: 188 casos.] 0 envio de bulbos oculares e tecidos perioculares para histopatologia na rotina diagnóstica e pesquisa ainda é incipiente no Brasil, diferentemente da área de oftalmologia clínica veterinária. Neste estudo, olhos e tecidos perioculares de animais domésticos

${ }^{1}$ Received on September 30, 2016.

Accepted for publication on January 19, 2017.

${ }^{2}$ Setor de Patologia, Departamento de Clínica e Cirurgia, Escola de Veterinária, Universidade Federal de Minas Gerais (UFMG), Av. Antônio Carlos 6627, Belo Horizonte, MG 31270-901, Brazil. *Corresponding author: ecco@vet.ufmg.br

${ }^{3}$ Department of Pathobiological Sciences, School of Veterinary Medicine, Louisiana State University, Baton Rouge, LA, USA.
}

e silvestres, especialmente provenientes do estado de Minas Gerais, Brasil, foram avaliados entre fevereiro de 2012 e setembro de 2015. As amostras foram analisadas macro e microscopicamente. Em algumas amostras, histoquímica e imuno-histoquímica também foram realizadas. Frequência, tipo de alteração ocular, espécie animal e estrutura ocular e/ou periocular acometidas foram registrados. Foram examinados 188 bulbos oculares e tecidos perioculares de animais domésticos e, ocasionalmente, silvestres. Nove animais apresentaram duas alterações concomitantes, totalizando 197 alterações. Doenças neoplásicas foram as mais frequentes (92), seguidas pelas traumáticas (43), inflamatórias (37), degenerativas (18), de desenvolvimento (4) e vasculares/hemorrágicas (3). 0 bulbo ocular foi a estrutura mais acometida (112), seguida pelas 
pálpebras (52), terceira pálpebra (17), conjuntiva bulbar (14) e região retrobulbar (2). Neoplasmas com origem em tecido periocular foram a alteração mais frequente (60), possivelmente relacionado a uma rotina cirúrgica mais ativa e consequente solicitação de avaliação histopatológica. Muitos animais apresentaram lesões oculares como reflexo de doença sistêmica, as quais foram diagnosticadas por necropsia e análise de outros órgãos. Particularmente em casos de neoplasia, detecção precoce e tratamento cirúrgico podem evitar envolvimento sistêmico. Ademais, a avaliação histopatológica ocular é capaz de oferecer melhor caracterização e prognóstico de condições clínico-patológicas do paciente animal.

TERMOS DE INDEXAÇÃO: Doenças oculares, doenças perioculares, patologia ocular veterinária, doenças inflamatórias, doenças degenerativas, doenças traumáticas, lesões proliferativas, caninos, felinos, patologia.

\section{INTRODUCTION}

Veterinary ophthalmology is a recent field. The first descriptions of veterinary ocular diseases are dated from the beginning of the twentieth century, and the first specializations in veterinary ocular pathology occurred at the beginning of the 1960's (Gelatt 2008). Ocular pathology is the field dedicated to studying the pathologic processes of ocular and periocular tissues (Orellana \& Pifano 2006). Scientific studies of natural and experimental ocular and periocular conditions in veterinary medicine are still incipient in Brazil. This scenario prevails due to relative low frequency of specimen submission to gross and microscopic examination. An important factor that contributes to this scenario is the lack of acknowledgment of veterinary clinicians/surgeons regarding the importance of histopathology for diagnosis and, consequently, prognosis for the animal patient. Financial factors related to many low income owners may contribute to the non-performance of ancillary exams. Furthermore, unfamiliarity with fixation and processing methods for eyes also contributes to the shortage of ocular pathology experts. Thus, frequency studies of ocular pathology alterations are rare in Brazil. Of 33,075 histopathologic evaluations in a 50-year retrospective study conducted in Southern Brazil, only 1,63\% were of ocular or periocular lesions (Martins \& Barros 2014). Another study was also conducted in Southern Brazil, focused mainly on ocular and periocular neoplastic diseases of cats and dogs (Hesse et al. 2015). This study aims to determine the frequency, anatomical localization and causes of ocular diseases in animals in Southeastern Brazil based on gross and histologic evaluation.

\section{MATERIALS AND METHODS}

One hundred eighty-eight ocular and periocular tissues with macroscopic alterations were examined. The samples were mainly from the state of Minas Gerais, Brazil, and were either surgically excised (125/188) or removed during necropsy (63/188), according to the norms approved by the Committee for Ethics and Animal Experimentation (CEUA, 262/2014) at the Universidade Federal de Minas Gerais (UFMG). The study extended over a 43-month period, between February 2012 and September 2015. During necropsies, the globes were removed and entirely submerged in a fixative solution (either Davidson's or 10\% buffered formalin) for 24 hours.
The periocular tissues as well as samples of other organs were fixed in $10 \%$ buffered formalin.

After 24 hours, the globes were sectioned adjacent to the optic nerve and perpendicular to the long posterior ciliary arteries, preserving the lens. The globes were then kept in the fixative for another 12 hours and later transferred to $70 \%$ ethanol until routine paraffin embedding and Hematoxylin and Eosin (HE) staining (Luna 1968).

In some cases, depending on the presumptive histopathologic diagnosis, histochemistry was performed: Periodic Acid-Schiff (PAS), Masson's trichrome, and Goodpasture (Luna 1968).

Immunohistochemistry (IHC) was performed in some other cases, for $\mathrm{T}$ lymphocytes (anti-CD3; DAKO ${ }^{\circledR}$, California, USA; anti-rabbit/human polyclonal, 1:300 dilution) and for Müller cells (Glial Fibrillary Acidic Protein, GFAP, DAKO ${ }^{\circledR}$, California, USA; anti-rabbit/bovine polyclonal, 1:500 dilution). In cases with suspicion of Leishmania involvement, anti-Leishmania hyperimmune serum (1:100 dilution) of a naturally infected dog was utilized (Tafuri et al. 2004). The IHC technique comprised incubation for 16 hours, indirect immunoperoxidase labeling with streptavidin-biotin kit $\left(\mathrm{DAKO}^{\circledR}\right)$, and detection with DAB (Spring Bioscience ${ }^{\circledR}$, Pleasanton, CA, USA).

The samples were grossly and microscopically evaluated and grouped according to species, lesion (developmental, degenerative, traumatic, inflammatory, vascular/hemorrhagic and neoplastic), and anatomic location. Animals that presented bilateral lesions were recorded only once.

\section{RESULTS}

Of 188 examined ocular and periocular tissue samples, nine animals had two concurrent alterations, totalizing 197 lesions. Ocular and periocular tissues of dogs $(125 / 188,5.85 \%)$, cats (26/188, 13.82\%), backyard chickens $(11 / 188,66.48 \%)$, horses $(11 / 188,5.85 \%)$, cattle $(5 / 188,2.65 \%)$, oncilla (Leopardus tigrinus) $(2 / 188,1.06 \%)$, broilers $(1 / 188,0.53 \%)$, scaly-headed parrot (Pionus maximiliani) (1/188, 0.53\%), pampas fox (Lycalopex gymnocercus) (1/188, 0.53\%), guinea pig (Cavia porcellus) (1/188, 0.53\%), camelid (llama) (1/188, 0.53\%), goat $(1 / 188,0.53 \%)$, equid (asinine) $(1 / 188,0.53 \%)$ and marmoset (Callithrix sp.) (1/188, 0.53\%) were evaluated.

In total, there were four alterations of ocular development, 18 degenerative, 43 traumatic (21 confirmed and 22 presumptive), three vascular/hemorrhagic, 37 inflammatory (19 of determined and 18 of undetermined cause), and 92 proliferative lesions (88 neoplasms and four tumor-like). Among the 197 lesions, 112 were located in the globe, 52 in the eyelids, 17 in the third eyelid, 14 in the bulbar conjunctiva, and two in the retrobulbar region.

Among the animals with developmental alterations of the eye (4/197, 2.03\%), two presented microphthalmia, a foal and a kitten (Fig.1A and B). Concurrent unilateral keratitis and hyphema in the foal were attributed to secondary trauma due to lateral recumbency. Both animals had bilateral aphakia and anterior segment dysgenesis. The cat also presented palpebral agenesis. The two other cases consisted of a dog with a corneal dermoid cyst and a dog with ectopic cilia.

Degenerative abnormalities were diagnosed in 18 animals of this study $(18 / 197,9.13 \%)$, comprising seven backyard chickens, seven dogs and four cats (Table 1). The dogs presented cystoid degeneration of the peripheral retina and the cat, of 


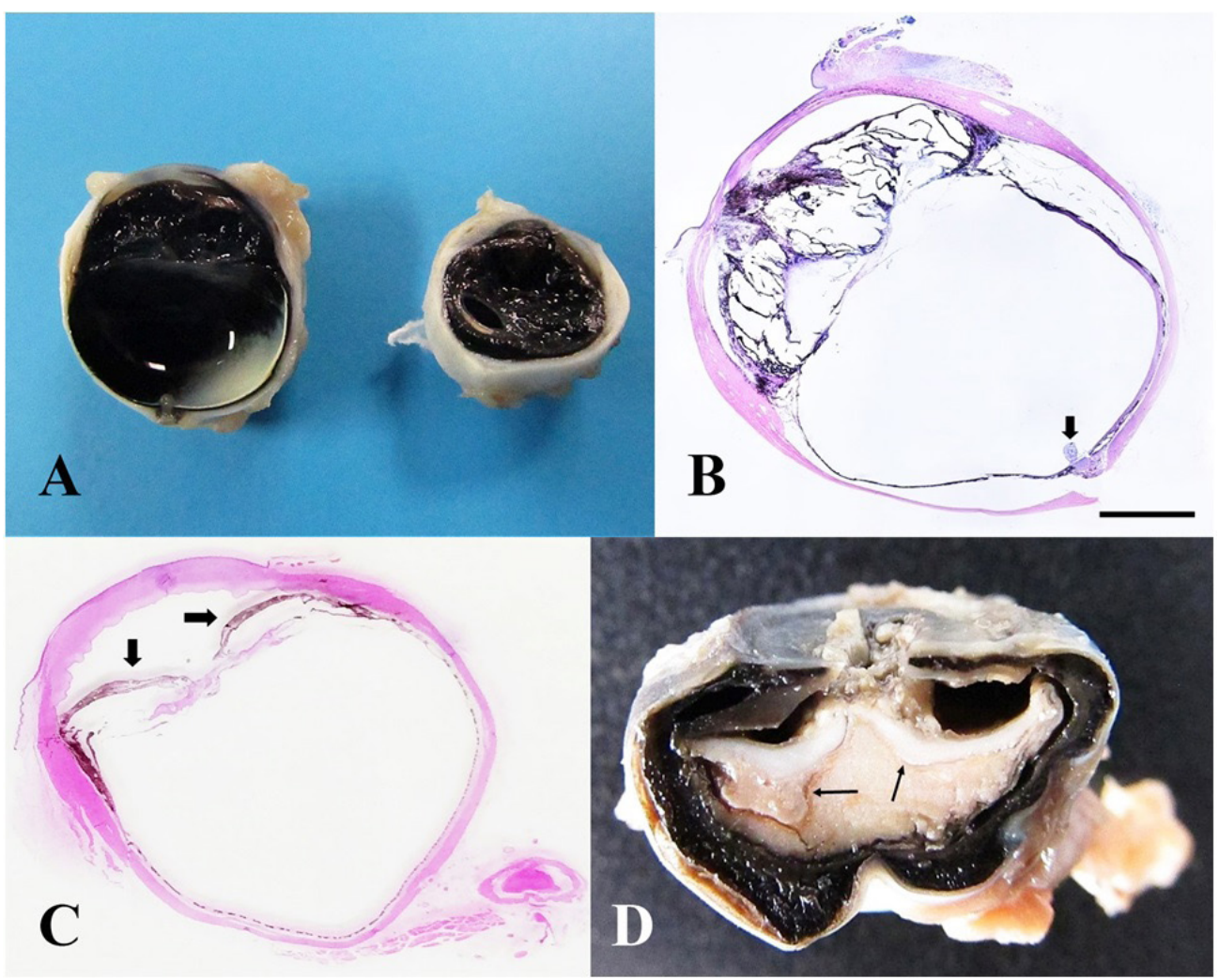

Fig.1. Animals with ocular diseases. (A) OU, kitten (2 months of age). Small eyes with anterior segment dysgenesis and aphakia. (B) OS, kitten (from A), with anterior segment dysgenesis, aphakia and attachment site at the optic disc of the otherwise completely detached retina (arrow). (HE, bar $=2100 \mu \mathrm{m})$. (C) OS, dog. Iris adherence to the lens capsular bag (posterior synechiae), with iris bombé formation (post phacoemulsification complications). HE, subgross image. (D) Eye, Pionus maximiliani. Corneal perforation with intraocular white-yellowish exudate and complete retinal detachment (arrows).

Table 1. Degenerative ocular lesions in animals

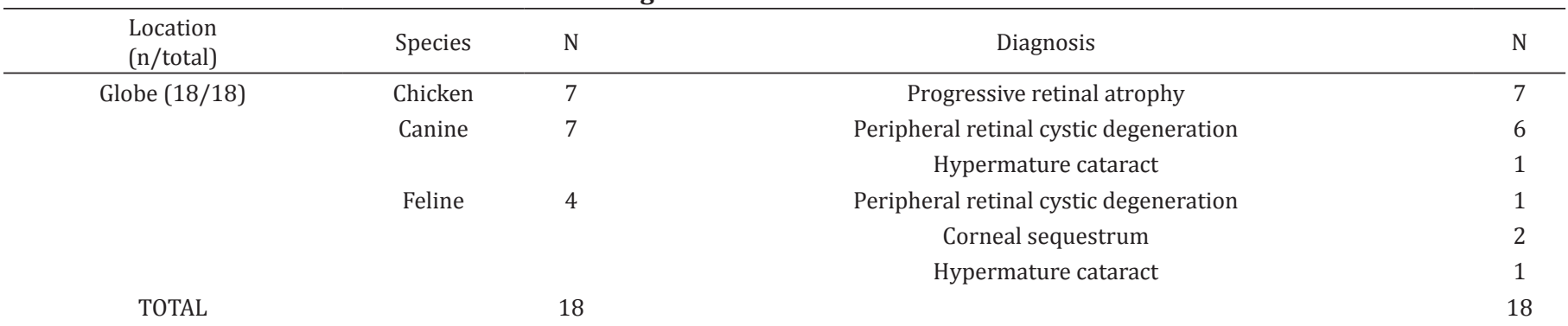

the pars plana of the ciliary body. In another dog and cat, there was hypermature cataract consistent with diabetes mellitus (confirmed by biochemistry parameters in the dog). Two cats had corneal sequestrum. The backyard chickens had progressive retinal atrophy. In two of these, there were early changes, mostly characterized by photoreceptor degeneration, and in the other five there were more severe and advanced lesions, characterized by loss of all retinal layers and by Müller cell proliferation, in addition to cataractous changes.

Traumatic diseases were diagnosed in the eyes of 43 animals (43/197, 21.82\%), specifically in 26 dogs, seven cats, three cattle, two horses, one asinine, one pampas fox (Lycalopex gymnocercus), one oncilla (Leopardus tigrinus), one goat and one scaly-headed parrot (Pionus maximiliani). Of these, 22 eyes were obtained through enucleation (two without history) and 21 eyes at necropsy. Most of the animals had a history of trauma; others had difficulty walking due to neurological or systemic diseases, with consequent involuntary movements and/or recumbency resulting in blunt ocular trauma. Of the 22 enucleated eyes 20 had clinical history and proper ophthalmic examination, including 14 cases evaluated immediately after the incident revealing acute and subacute alterations (buphthalmos and exophthalmos/proptosis, acquired ankyloblepharon and symblepharon, keratitis, descemetocele, corneal and scleral perforation and iris prolapse). Six cases were examined in advanced stages of disease, with established chronic secondary glaucoma or phthisis bulbi. Globes with traumatic lesions had all tunics affected, with the anterior uvea and the cornea most frequently affected (Fig.2). Grossly, there were keratoconjunctivitis, descemetocele, corneal and 
scleral perforation, hyphema, hypopyon, iris prolapse, and lens luxation and prolapse. Microscopically, there were Descemet membrane duplication with descemetization and endothelialization, iridocyclitis, panuveitis, endophthalmitis, intraocular hemorrhage, pre-iridal and choroidal fibrovascular membrane, anterior and posterior synechiae, cataract, retinal detachment, scleritis, and periocular hemorrhage (Fig.1C and D). Retinal atrophy (of variable severity) was related to glaucoma.

Three dogs had vascular/hemorrhagic disorders in the globes $(3 / 197,1.52 \%)$. Two of them presented diffuse congestion at gross examination, associated with carbamate poisoning. One of these two dogs had rodenticide in the stomach. The third dog had clinical, gross and histologic alterations consistent with chronic kidney disease, with vascular fibrinoid necrosis in different organs, including retina and choroid, accompanied by intraocular hemorrhage and retinal detachment.

Inflammatory diseases in the ocular and periocular tissues were found in 37 animals $(37 / 197,18.78 \%)$. Among these, the dog was the most affected species, followed by horses, cats, cattle, backyard chickens, broilers, guinea pig (Cavia porcellus), oncilla (Leopardus tigrinus), camelid (llama) and marmoset (Callithrix sp.). Of the 37 inflammatory cases, 26 affected the globe, four of which were obtained through enucleation. In 19 of the 37 animals, it was possible to determine the etiology, four of which were also associated with intraocular and periocular proliferative lesions. Of these 19 animals, 13 were from dogs (six globes, six eyelids, and one bulbar conjunctiva), two backyard chickens, one cat, one broiler, one llama and one guinea pig. In 18 animals, the cause of the inflammatory disorder was not established, consisting of 10 dogs (seven globes and three third eyelids), three horses (globes), two cattle (globes), one cat (third eyelid), one oncilla (globe) and one marmoset (globe). All ocular and periocular structures were affected, with uveitis as the major alteration (Fig.3). Of the 19 animals with a defined etiology, six were caused by bacteria (Escherichia coli in two backyard chickens, in one broiler and in one llama; Streptococcus zooepidemicus in one Guinea pig; and gram positive cocci in one dog); five by protozoa (Leishmania sp.), resulting in uveitis and keratoconjunctivitis; two by presumptive viruses (canine distemper in one dog and feline infectious peritonitis (FIP) in one cat); and six were non-infectious (chalazion/lipogranuloma, associated with Meibomian gland proliferative lesions). In the llama, E. coli was cultured from thromboembolic nephritis. In the Guinea pig, $S$. zooepidemicus was cultured from cervical abscesses. Of the 18 animals with undetermined inflammatory causes, septicemia was suspected in one dog and two horses based on gross and histopathology findings, and Moraxella spp. infection was suspected in two cattle (Fig.4).

Proliferative lesions were found in 92 cases (92/197, 46.70\%), 19 affecting globes and 73 periocular tissues (Fig.5). The dog was the most affected species (72), followed by cats (13), horses (5) and backyard chickens (2) (Table 2). The most affected site was the eyelid and third eyelid, followed by globe and retrobulbar region. Malignant neoplasms outnumbered the benign ones, which included few tumor-like alterations (hyperplasia and prolapse of the gland of the third eyelid, cherry eye). One dog had a bulbar conjunctival hemangiosarcoma with corneal invasion and abundant intrahistiocytic Leishmania sp. amastigotes within both the interstitium and the neoplastic blood channels. Another dog had bilateral anterior uveal lymphoma.

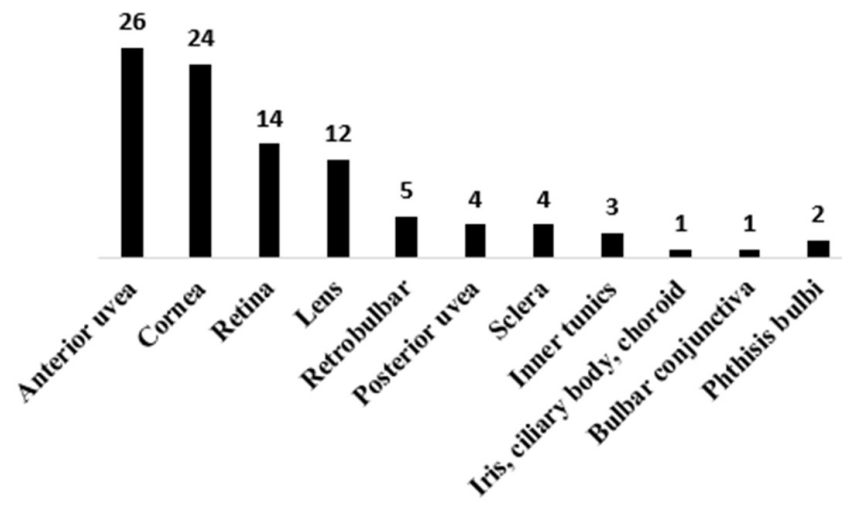

Fig.2. Animals with ocular diseases. Frequency and location of traumatic alterations.

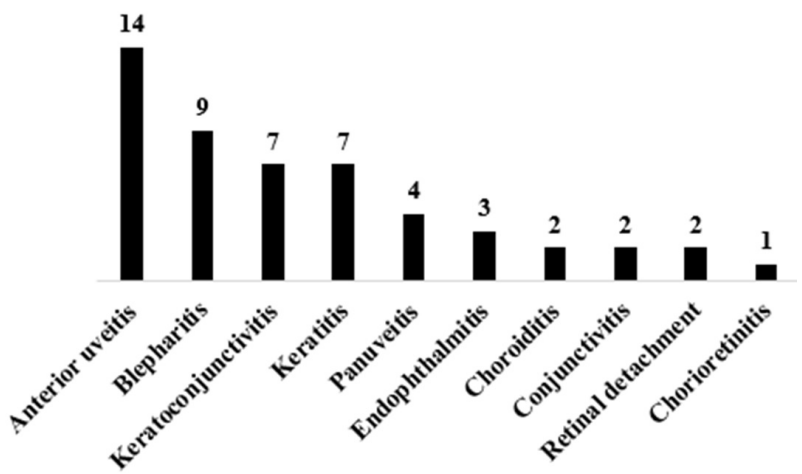

Fig.3. Animals with ocular diseases. Frequency and type of inflammation of ocular and periocular tissues.
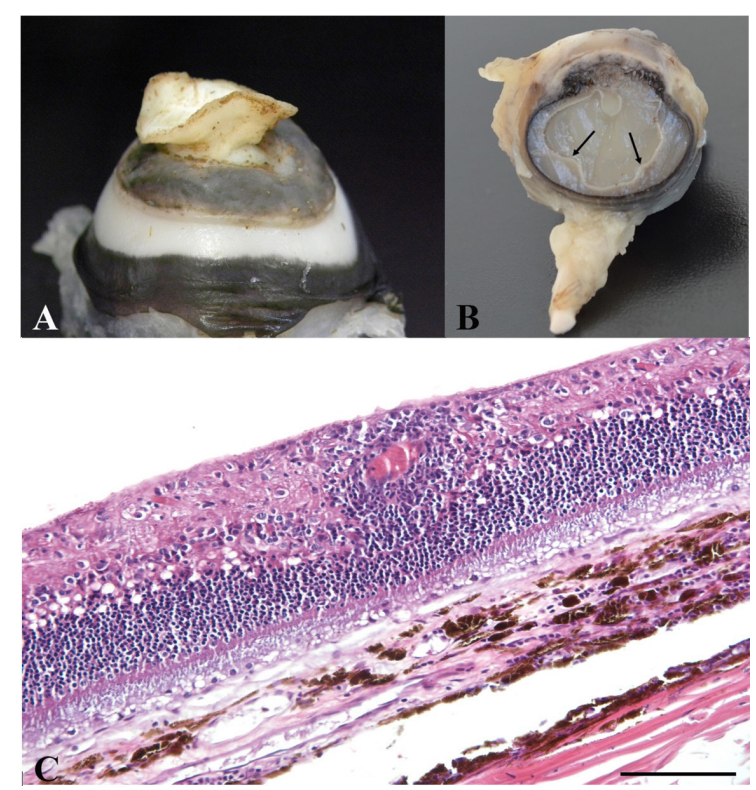

Fig.4. Animals with ocular diseases. (A) OS, bovine. Central chronic corneal ulcer and iris prolapse (presumptive Moraxella sp. infection). (B) OS, dog. Exudate in all ocular chambers and retinal detachment (arrows) (visceral leishmaniasis-associated panuveitis). (C) Retina, dog. Retinal and choroidal perivascular lymphoplasmacytic inflammatory infiltrate (arrow) (chorioretinitis) (presumptive canine distemper virus infection). HE, obj.20x, bar $=100 \mu \mathrm{m}$. 


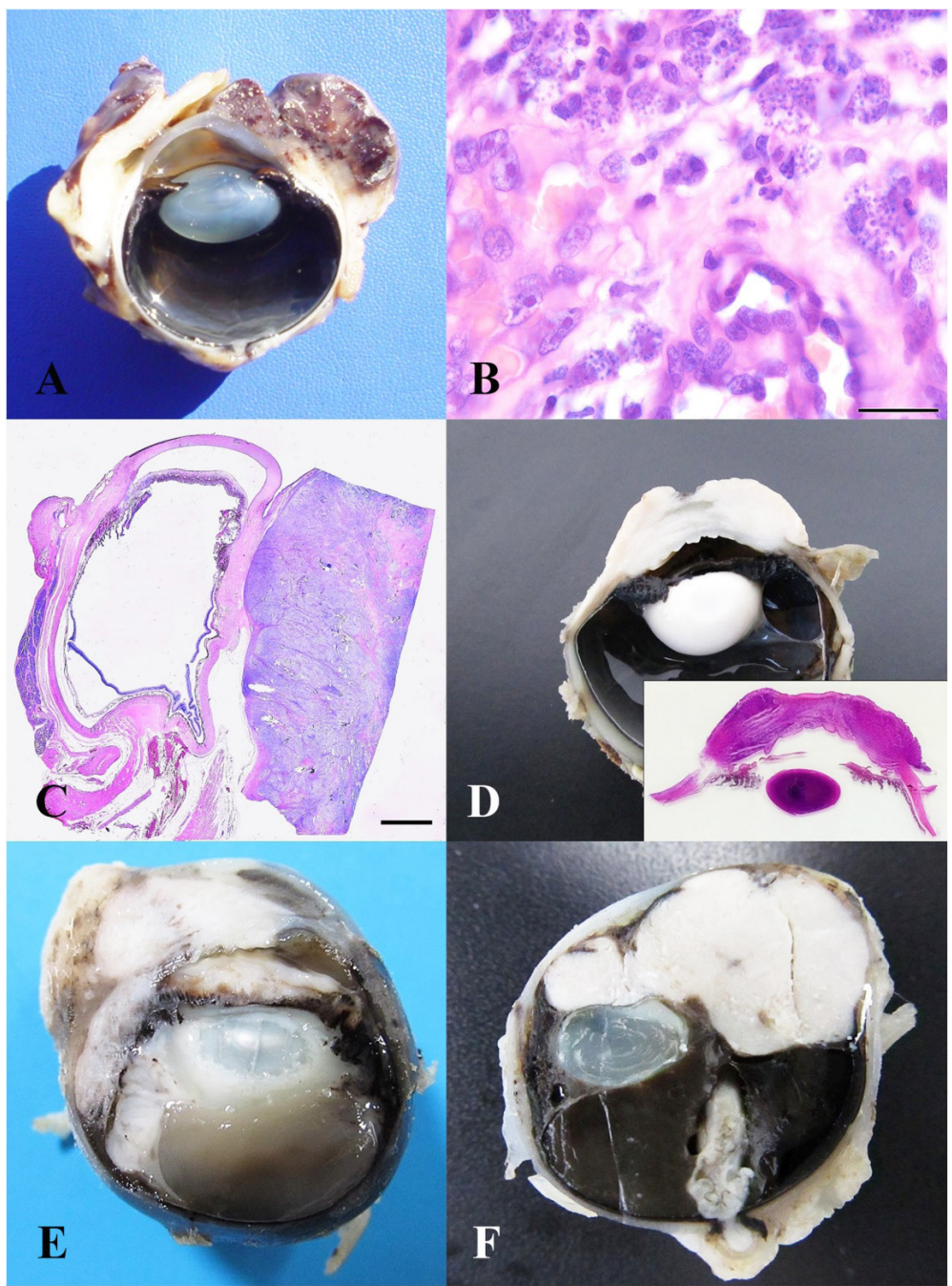

Fig.5. Animals with ocular diseases. (A) Eye, dog. Red irregular mass in the bulbar conjunctiva with corneal invasion (hemangiosarcoma). (B) Histology of A illustrating the mesenchymal neoplastic cell proliferation forming irregular blood channels (hemangiosarcoma) with interspersed Leishmania sp. amastigotes in tumor infiltrating macrophages. HE, obj.100x, bar $=20 \mu \mathrm{m}$. (C) Eye, dog. Bulbar conjunctiva expanded by solid cellular proliferation, with retrobulbar extension and ocular compression (lymphoma). HE, bar $=280 \mu \mathrm{m}$. (D) Davidson's fixed OD, horse. Diffusely thickened and irregularly shaped whitish bulbar conjunctiva and cornea (corneal stromal invasive squamous cell carcinoma). Inset: subgross image of cornea infiltrated by the neoplasm. (E) OS, cat. Bulbar conjunctiva with a white solid mass that invades the cornea and anterior uvea (fibrosarcoma). (F) Eye, dog. Anterior uvea thickened by a white, solid mass (lymphoma), associated with posterior subluxation of the lens, severe diffuse vitreal hemorrhage and complete retinal detachment.

Table 2. Proliferative lesions in ocular and periocular tissues of animals

\begin{tabular}{|c|c|c|c|c|}
\hline Location (n/total) & Species & $\mathrm{N}$ & Diagnosis & $\mathrm{N}$ \\
\hline \multirow[t]{9}{*}{ Eyelids (41/92) } & Canine & 34 & Meibomian gland epithelioma & 17 \\
\hline & & & Papilloma & 4 \\
\hline & & & Mast cell tumor & 2 \\
\hline & & & Squamous cell carcinoma & 1 \\
\hline & & & Fibrosarcoma & 1 \\
\hline & & & Benign peripheral nerve sheath tumor & 1 \\
\hline & & & Hemangiosarcoma & 1 \\
\hline & & & Melanoma & 1 \\
\hline & Equine & 1 & Squamous cell carcinoma & 1 \\
\hline
\end{tabular}


Table 2. Continued...

\begin{tabular}{|c|c|c|c|c|}
\hline Location (n/total) & Species & $\mathrm{N}$ & Diagnosis & $\mathrm{N}$ \\
\hline Bulbar conjunctiva & Canine & 10 & Hemangiosarcoma & 5 \\
\hline \multirow[t]{4}{*}{$(13 / 92)$} & & & Lymphoma & 3 \\
\hline & & & Melanoma & 2 \\
\hline & Equine & 2 & Squamous cell carcinoma & 2 \\
\hline & Feline & 1 & Fibrosarcoma (with corneal and iridal invasion) & 1 \\
\hline Palpebral conjunctiva (4/92) & Canine & 4 & Melanoma & 4 \\
\hline \multirow[t]{5}{*}{ Third eyelid (13/92) } & Canine & 13 & Hyperplasia and prolapse of the gland of the third eyelid (cherry eye) & 4 \\
\hline & & & Adenocarcinoma & 5 \\
\hline & & & Hemangiosarcoma & 2 \\
\hline & & & Melanoma & 1 \\
\hline & & & Squamous cell carcinoma & 1 \\
\hline \multirow[t]{9}{*}{ Globe (19/92) } & Canine & 9 & Anterior uveal melanoma & 4 \\
\hline & & & Posterior uveal melanoma & 1 \\
\hline & & & Anterior uveal melanocytoma & 1 \\
\hline & & & Anterior uveal lymphoma & 3 \\
\hline & Feline & 6 & Diffuse iris melanoma & 3 \\
\hline & & & Anterior uveal lymphoma & 2 \\
\hline & & & $\begin{array}{l}\text { Post-traumatic ocular sarcoma (chondrosarcoma) with parietal pleural and } \\
\text { pulmonary metastases }\end{array}$ & 1 \\
\hline & Equine & 2 & Corneal stromal invasive squamous cell carcinoma & 2 \\
\hline & Chicken & 2 & Lymphoma (ocular Marek) & 2 \\
\hline \multirow[t]{2}{*}{ Retrobulbar (2/92) } & Canine & 2 & Metastatic lymphoma & 1 \\
\hline & & & Malignant peripheral nerve sheath tumor & 1 \\
\hline TOTAL & & 92 & & 92 \\
\hline
\end{tabular}

\section{DISCUSSION}

Ocular and periocular tissues included in this study were most frequently from dogs. This corroborates the data collection from Dubielzig et al. (2010) and the study of Martins \& Barros (2014). The second most frequent species in this study was the cat, in contrast to Martins \& Barros' study (2014), in which cattle were the second most frequent species. Regarding anatomical location, the globe was the main examined sample, opposed to Martins \& Barros (2014), where the eyelids were the main ones. Among ocular diseases, the proliferative lesions predominated in the ocular and periocular tissues, similarly to the study conducted by Dubielzig et al. (2010) and Martins \& Barros (2014). Nevertheless, considering only the globe, traumatic lesions prevailed over the proliferative ones. The frequency variability among animal species might be due to the animal population within the respective geographical region. The difference in anatomical locations might be the result of a larger number of post-mortem compared to surgical biopsies included in this study than in that by Martins \& Barros (2014).

Eye developmental abnormalities comprise a low frequency in pathology diagnostic centers, corresponding to $2 \%$ of all alterations in an ocular pathology laboratory with a high case load in the United States of America (Dubielzig et al. 2010). A similar frequency was also seen in this study. Data on frequency of microphthalmia in different species are scarce. Eight cases of microphthalmia in white-tailed deer (Fulton et al. 1977) and six cases in horses were previously reported; however, there is none involving domestic cats (Dubielzig et al. 2010).
Degenerative diseases comprised $9.13 \%$ of all alterations in this study. Avian progressive retinal degenerative diseases were reported in chickens (Ulshafer et al. 1984, Ulshafer \& Allen 1985) and broilers (Curtis et al. 1988), with no previous reports in Brazil. Retinal degeneration is a post-natal condition that generally begins by affecting photoreceptors and progresses to diffuse retinal atrophy, possibly resultant of hereditary causes in chickens (Ulshafer \& Allen 1985). Peripheral retinal cystic degeneration is a common incidental finding in old dogs (Dubielzig et al. 2010, Wilcock \& Njaa 2016). The etiopathogenesis of this condition is still obscure, but it is known that there is deposition of hyaluronic acid within the cysts (Wilcock \& Njaa 2016). Cataract can be primary (hereditary) or secondary to lens rupture, neoplasia, endophthalmitis, anterior segment dysgenesis, solar irradiation, diabetes mellitus, senility, progressive retinal atrophy, and nutritional excesses or deficiencies (Dubielzig et al. 2010, Wilcock \& Njaa 2016). In the present study, cataract was associated with progressive retinal atrophy in chickens and diabetes mellitus in one dog and one cat. As seen in this study, diabetic cataract is usually bilateral, beginning in the equatorial and cortical regions, with progression to diffuse involvement in severe cases (Wilcock \& Njaa 2016).

Traumatic lesions comprised $21.82 \%$ of all cases, similarly to the 15\% frequency reported by COPLOW (Dubielzig et al. 2010). This is in contrast to Martins \& Barros' (2014) study of which only $0.88 \%$ of all cases were related to traumatic events. The main ocular structure affected by trauma in this study was the cornea. Corneal ulcers are the main finding in equine ophthalmic evaluation (Brooks 2002, Reichmann et al. 2008) and are frequently trauma-related (Reichmann et al. 2008). 
Regardless of the traumatic event, intraocular complications include proliferation of lens epithelial cells and of nonpigmented ciliary epithelium; pre- and post-iridal fibrovascular membranes, inducing anterior and posterior synechiae; and choroidal fibrovascular membrane, with consequent subretinal hemorrhage and retinal detachment. Hemorrhage may also occur in the anterior, posterior and vitreous chambers, frequently associated with blunt or penetrating-perforating injuries (Dubielzig et al. 2010). In the present study, there was acute corneal and/or scleral perforation in multiple animal species presenting histologic lesions similar to the ones reported by Rampazzo et al. (2006). Advanced stages of trauma culminating in phthisis bulbi were also present, as already reported by Dubielzig et al. (2010) and Wilcock \& Njaa (2016). An unexpected finding in some of the dogs affected by trauma in this study was Descemet membrane duplication with descemetization and endothelialization as reported by Kafarnik et al. (2009). This alteration seems to be infrequently observed, since it was present in only $0.6 \%$ of all canine submissions at COPLOW (Kafarnik et al. 2009).

Ocular hemorrhage is defined by blood within the globe, accompanied or not by blood vessel alterations. Intraocular hemorrhage can be caused by coagulation disorders, which may be due to hereditary or acquired thrombocytopenia (Grahn et al. 1997, Komáromy et al. 1999, Mitchell 2006). Nevertheless, there are a variety of other causes of intraocular hemorrhage, such as trauma, systemic hypertension, intraocular neoplasms, retinal detachment, congenital abnormalities (Collins \& Moore 1991, Komáromy et al. 1999, Slatter 2005, Mitchell 2006), blood dyscrasias (Collins \& Moore 1991, Komáromy et al. 1999, Mitchell 2006) and pre-iridal fibrovascular membrane (Peiffer et al. 1990, Slatter 2005). Carbamate poisoning generally leads to systemic congestion (Siqueira et al. 2015), including of blood vessels of the eye. In the present study, two dogs had generalized congestion, with carbamate poisoning confirmed in one and suspected in the other. The dog with vascular "fibrinoid" necrosis had systemic hypertension associated with chronic kidney disease, as described by Maggio et al. (2000), Dubielzig et al. (2010), Cianciolo \& Mohr (2016) and Robinson \& Robinson (2016).

Inflammatory diseases of the ocular and periocular tissues in this study (18.78\%) were less frequent than in COPLOW's case series (Dubielzig et al. 2010), where they comprised $29 \%$ of the collection. The causes were varied, as also observed at COPLOW, and can include fungi, bacteria, viruses, parasites and protozoa (Dubielzig et al. 2010, Wilcock \& Njaa 2016). In the present study, of the 19 cases with inflammatory lesions with a defined cause, six were non-infectious (chalazion/ lipogranuloma), six bacterial, five protozoal (caused by Leishmania sp.), and two strongly suggestive of viral infection. The etiology is frequently not identified (Mitchell 2006), as was the case in 18/37 animals of this study. Regarding bacterial agents, any species is capable of inducing bacteremia and septicemia with consequent ocular inflammation; however, the most frequent ones are cocci (Wilcock \& Njaa 2016). In our collection, intralesional cocci and coccobacilli were seen in two chickens, one broiler (Escherichia coli), one dog (gram positive cocci) and one Guinea pig (Streptococcus zooepidemicus). In the latter, bacteria were isolated from a cervical abscess that likely caused bacteremia. Gruszynski et al. (2015) stress the zoonotic potential of $S$. zooepidemicus involving humans exposed to
Guinea pigs, from which the bacterium was already isolated in healthy animals. E. coli was isolated from thromboembolic nephritis in a camelid (llama), thought to have similarly led to septicemia with ocular involvement. The protozoa Toxoplasma, Neospora, Leishmania, Besnoitia and Trypanosoma can also infect the eye; however, according to Wilcock \& Njaa (2016), only Toxoplasma/Neospora would have the ability to evoke primary intraocular lesions. In the current study, four dogs had uveitis and one had keratoconjunctivitis associated with visceral leishmaniasis, as also reported by Brito et al. (2006) and Peña et al. (2008). In another dog of this study, there were lesions strongly consistent with viral infection, such as perivascular lymphoplasmacytic panuveitis and retinitis, possibly caused by canine distemper virus (Jubb et al. 1957). In one cat that died due to FIP, the globe had diffuse, severe, lymphoplasmacytic and histiocytic iridocyclitis.

Proliferative lesions were the most prevalent finding in our samples (46.70\%). They represented 39\% of the case series reported by Dubielzig et al. (2010) and 79.1\% in the retrospective study of Martins \& Barros (2014) in Southern Brazil. In the latter study, the most frequent species affected by neoplasia was the dog, followed by cattle, cats, horses, sheep and rabbits. A retrospective study performed in Paraná gathered 970 neoplasms in animals in a 22-year period. The ocular ones comprised $5.56 \%$ and the most affected species were cattle, dogs, cats, horses, goats and mice (Werner et al. 1998). In the study conducted by Hesse et al. (2015), ocular neoplasms were evaluated in cats and dogs only, with the latter representing the most affected species. In our collection, the descending order of frequency was dogs, cats, horses and chickens. These varied data are probably related to the difference in animal species referred to necropsy and histopathology in those diagnostic centers.

Regarding tumor location, in Martins \& Barros' study (2014), there were 214 neoplasms affecting the eyelid, 64 the eye (41 exact location not informed), 51 the third eyelid, 19 the conjunctiva, five the orbit, and three the lacrimal gland. These data enforce our data set. Similarly, Hesse et al. (2015) reported that eyelids represented the most frequent location of neoplastic changes, both in dogs and cats.

In our study, benign neoplasms comprised $34.78 \%$, malignant tumors, $60.86 \%$, and tumor-like lesions, $4.34 \%$. In Werner et al.'s (1998) study, benign tumors were represented by $18.6 \%$ and the malignant ones by $81.4 \%$ of the cases. Hesse et al. (2015) reported that benign tumors were more frequent in dogs (56\%) and malignant tumors were more frequent in cats $(75.8 \%)$.

Melanocytic tumors are the most common intraocular neoplasms in dogs and they generally have a benign biologic behavior (Turner 2010, Wilcock \& Njaa 2016), contrasting with this study. Approximately $15 \%$ of all canine melanocytic neoplasms of the anterior uvea are reportedly malignant, with a 5\% metastatic rate (Wilcock \& Njaa 2016). Regarding cats, the metastatic rate increases (Turner 2010), reaching 19\% (Wiggans et al. 2016). In the present study, we diagnosed eight melanomas (five anterior uveal and choroidal melanomas in dogs; three diffuse iris melanomas in cats) and only one anterior uveal melanocytoma in a dog. Melanomas were therefore more frequent in dogs in this study than melanocytomas. Probably, full case work-up, including submission for histopathology, was more common 
in animals with more aggressive neoformation. Melanocytic tumors of the anterior uvea are more frequently diagnosed than the choroidal ones, possibly due to the infrequent ocular fundus examination (fundoscopy) (Dubielzig et al. 1985). Feline ocular post-traumatic sarcoma may arise within five months to 11 years after the presumed ocular injury (e.g. trauma) (Wilcock \& Njaa 2016). In our study, a cat with intraocular chondrosarcoma, probably post-traumatic, died due to multiple metastases to the parietal pleura and lungs. Ante-mortem diagnosis and early removal of this ocular tumor could have prevented the metastatic event and the animal's death, which stresses the importance of ocular histopathology examination. In contrast, metastases to the eye are infrequent (Dubielzig et al. 2010, Wilcock \& Njaa 2016) and, when they happen, may be uni- or bilateral. Likewise, a dog had bilateral anterior uveal lymphoma. This most likely represented metastatic spread of the neoplasm to the globe; however, since the specimens were collected during surgery and submitted without proper history, clinical examination and follow-up, it was not possible to determine whether the lymphoma was primary ocular or metastatic.

\section{CONCLUSIONS}

In our 43-month long study of ocular and periocular diseases, the dog was the species most frequently affected, and the globe represented the main involved structure.

Overall, malignant neoplasms were the most frequent finding.

When only the globe but not the periocular tissue was taken in consideration, traumatic lesions were the most common.

In Brazil, many veterinarians have yet to recognize the importance of sending enucleated eyes for histopathological examination.

The consequential low number of eyes submitted to a diagnostic laboratory may therefore underestimate the results of such a study, as well as contribute for ocular pathology to remain an unfamiliar field to many pathologists. Histopathologic evaluation of surgical ocular and periocular specimens may provide a better understanding of the affected animal's clinical-pathological condition and assist in making adequate therapeutic decisions to prevent the patient's discomfort and death.

Acknowledgements.- The authors thank Coordenação de Aperfeiçoamento de Pessoal de Nível Superior (CAPES) and Conselho Nacional de Desenvolvimento Científico e Tecnológico (CNPq), Brazil (fellowships).

\section{REFERENCES}

Brito F.L.C., Alves L.C., Maia F.C.L., Santos E.S.C., Laus J.L. \& Meunier I.M.J. 2006. Ocular alterations in dogs naturally infected by Leishmania (Leishmania) chagasi. Arq. Bras. Med. Vet. Zootec. 58(5):768-775. http://dx.doi. org/10.1590/S0102-09352006000500011.

Brooks D.E. 2002. Equine Ophthalmology. Proc. AAEP 48:300-313.

Cianciolo R.E. \& Mohr F.C. 2016. Urinary system, p.384-388. In: Maxie M.G. (Ed.), Jubb, Kennedy, and Palmer's Pathology of Domestic Animals. Vol.2. 6th ed. Elsevier, Missouri. http://dx.doi.org/10.1016/B978-0-70205318-4.00010-3.
Collins B.K. \& Moore C.P. 1991. Canine anterior uvea, p.374-375, 382-383. In: Gelatt K.N. (Ed.), Veterinary Ophthalmology. 2nd ed. Lea and Febiger, Philadelphia.

Curtis R., Baker J.R., Curtis P.E. \& Johnston A. 1988. An inherited retinopathy in commercial breeding chickens. Avian Pathol. 17(1):87-99. http://dx.doi. org/10.1080/03079458808436430. PMid:18766669.

Dubielzig R.R., Aguirre G.D., Gross S.L. \& Diters R.W. 1985. Choroidal melanomas in dogs. Vet. Pathol. 22(6):582-585. http://dx.doi. org/10.1177/030098588502200612. PMid:4082384.

Dubielzig R.R., Ketring K.L., McLellan G.J. \& Albert D.M. 2010. Veterinary Ocular Pathology: a comparative review. Elsevier, Philadelphia. 456p.

Fulton A.B., Albert D.M., Buyukmihci N., Wyand D.S. \& Stone W.B. 1977. Spontaneous anophthalmia and microphthalmia in white-tailed deer. J. Comp. Pathol. 87(4):557-568. http://dx.doi.org/10.1016/00219975(77)90062-7. PMid:591655.

Gelatt P.K.N. 2008. Veterinary ophthalmology: our past, present and future. Bull. Acad. Vet. Fr. 161(14):299-306. http://dx.doi.org/10.4267/2042/47955.

Grahn B.H., Wolfer J. \& Smedile L.E. 1997. Diagnostic ophthalmology. Can. Vet. J. 38(1):53-54. PMid:8993787.

Gruszynski K., Young A., Levine S.J., Garvin J.P., Brown S., Turner L., Fritzinger A., Gertz Jr R.E., Murphy J.M., Vogt M. \& Beall B. 2015. Streptococcus equi subsp. zooepidemicus infections associated with guinea pigs. Emerg. Infect. Dis. 21(1):156-158. http://dx.doi.org/10.3201/eid2101.140640. PMid:25531424.

Hesse K.L., Fredo G., Guimarães L.L.B., Reis M.O., Pigatto J.A.T., Pavarini S.P., Driemeier D. \& Sonne L. 2015. Neoplasmas oculares e de anexos em cães e gatos no Rio Grande do Sul: 265 casos (2009-2014). Pesq. Vet. Bras. 35(1):49-54. http://dx.doi.org/10.1590/S0100-736X2015000100011.

Jubb K.V., Saunders L.Z. \& Coates H.V. 1957. The intraocular lesions of canine distemper. J. Comp. Pathol. 67(1):21-29. http://dx.doi.org/10.1016/ S0368-1742(57)80003-4. PMid:13406120.

Kafarnik C., Murphy C.J. \& Dubielzig R.R. 2009. Canine duplication of Descemet's membrane. Vet. Pathol. 46(3):464-473. http://dx.doi.org/10.1354/vp.08VP-0183-K-FL. PMid:19176501.

Komáromy A.M., Ramsey D.T., Brooks D.E., Ramsey C.C., Kallberg M.E. \& Andrew S.E. 1999. Hyphema. I. Pathophysiologic considerations. Compend. Contin. Educ. Pract. Vet. 21(11):1964-1969.

Luna L.G. 1968. Manual of Histologic Staining Methods of the Armed Forces Institute of Pathology. 3rd ed. McGraw-Hill, New York. 258p.

Maggio F., DeFrancesco T.C., Atkins C.E., Pizzirani S., Gilger B.C. \& Davidson M.G. 2000. Ocular lesions associated with systemic hypertension in cats: 69 cases (1985-1998). J. Am. Vet. Med. Assoc. 217(5):695-702. http:// dx.doi.org/10.2460/javma.2000.217.695. PMid:10976302.

Martins T.B. \& Barros C.S.L. 2014. Fifty years in the blink of an eye: a retrospective study of ocular and periocular lesions in domestic animals. Pesq. Vet. Bras. 34(12):1215-1222. http://dx.doi.org/10.1590/S0100736X2014001200012.

Mitchell N. 2006. Hyphaema in dogs. UK Vet. 11(8):1-4.

Orellana M.E. \& Pifano I.A. 2006. Patología ocular para el patólogo general. Revta Oftalmol. Venez. 62(1):16-31.

Peiffer Jr R.L., Wilcock B.P. \& Yin H. 1990. The pathogenesis and significance of pre-iridal fibrovascular membrane in domestic animals. Vet. Pathol. 27(1):4145. http://dx.doi.org/10.1177/030098589002700106. PMid:2309380.

Peña M.T., Naranjo C., Klauss G., Fondevila D., Leiva M., Roura X., Davidson M.G. \& Dubielzig R.R. 2008. Histopathological features of ocular Leishmaniosis in the dog. J. Comp. Pathol. 138(1):32-39. http://dx.doi.org/10.1016/j. jcpa.2007.09.004. PMid:18048051. 
Rampazzo A., Eule C., Speier S., Grest P. \& Spiess B. 2006. Scleral rupture in dogs, cats, and horses. Vet. Ophthalmol. 9(3):149-155. http://dx.doi. org/10.1111/j.1463-5224.2006.00455.x. PMid:16634927.

Reichmann P., Dearo A.C.O. \& Rodrigues T.C. 2008. Ocorrência de doenças oftalmológicas em equinos utilizados para tração urbana na cidade de Londrina, PR. Ciência Rural 38(9):2525-2528. http://dx.doi.org/10.1590/ S0103-84782008000900017.

Robinson W.F. \& Robinson N.A. 2016. Cardiovascular system, p.59-60. In: Maxie M.G. (Ed.), Jubb, Kennedy, and Palmer's Pathology of Domestic Animals. Vol.3. 6th ed. Elsevier, Missouri. http://dx.doi.org/10.1016/ B978-0-7020-5319-1.00012-8.

Siqueira A., Salvagni F.A., Yoshida A.S., Gonçalves-Junior V., Calefi A.S., Fukushima A.R., Spinosa H.S. \& Maiorka P.C. 2015. Poisoning of cats and dogs by the carbamate pesticides aldicarb and carbofuran. Res. Vet. Sci. 102:142-149. http://dx.doi.org/10.1016/j.rvsc.2015.08.006. PMid:26412534.

Slatter D. 2005. Úvea, p.358, 373, 609. In: Slatter D. (Ed.), Fundamentos de Oftalmologia Veterinária. 3rd ed. Roca, São Paulo.

Tafuri W.L., Santos R.L., Arantes R.M., Gonçalves R., Melo M.N., Michalick M.S. \& Tafuri W.L. 2004. An alternative immunohistochemical method for detecting Leishmania amastigotes in paraffin-embedded canine tissues.
J. Immunol. Methods 292(1-2):17-23. http://dx.doi.org/10.1016/j. jim.2004.05.009. PMid:15350508.

Turner S.M. 2010. Oftalmologia em pequenos animais: série clínica veterinária na prática. Elsevier, Rio de Janeiro. 370p.

Ulshafer R.J. \& Allen C. 1985. Hereditary retinal degeneration in the Rhode Island red chicken: ultrastructural analysis. Exp. Eye Res. 40(6):865-877. http://dx.doi.org/10.1016/0014-4835(85)90131-9. PMid:4018169.

Ulshafer R.J., Allen C., Dawson W.W. \& Wolf E.D. 1984. Hereditary retinal degeneration in the Rhode Island red chicken. I. Histology and ERG. Exp. Eye Res. 39(2):125-135. http://dx.doi.org/10.1016/0014-4835(84)900034. PMid:6489467.

Werner P.R., Chiquito M., Pachaly J.R. \& Ferreira F.M. 1998. Neoplasias oculares diagnosticadas em animais do sul do Paraná, Brasil. Arq. Ciênc. Vet. Zool. UNIPAR 1(1):13-21.

Wiggans K.T., Reilly C.M., Kass P.H. \& Maggs D.J. 2016. Histologic and immunohistochemical predictors of clinical behavior for feline diffuse iris melanoma. Vet. Ophthalmol. 19(Suppl. 1):44-55. http://dx.doi.org/10.1111/ vop.12344. PMid:26805705.

Wilcock B.P. \& Njaa B.L. 2016. Special senses, p.407-508. In: Maxie M.G. (Ed.), Jubb, Kennedy, and Palmer's Pathology of Domestic Animals. Vol.1. 6th ed. Elsevier, Missouri. http://dx.doi.org/10.1016/B978-0-7020-5317-7.00005-9. 